\title{
Alterations on Growth and Gill Morphology of Danio rerio (Pisces, Ciprinidae) Exposed to the Toxic Sediments
}

\author{
Renata Fracácio $^{1 *}$, Nelsy Fenerich Verani ${ }^{2}$, Evaldo Luiz Gaeta Espíndola ${ }^{3}$, Odete Rocha ${ }^{4}$, \\ Odila Rigolin-Sá $^{5}$ and Cássio Arilson Andrade ${ }^{6}$ \\ ${ }^{1}$ PPG-ERN; DHB; UFSCar; São Carlos - SP - Brazil. ${ }^{2}$ PPG-ERN; DHB; UFSCAR; São Carlos - SP - Brazil. ${ }^{3}$ \\ PPG-SEA; CRHEA; SHS; USP; São Paulo - SP - Brazil. ${ }^{4}$ PPG-ERN; DEBE; UFSCar; São Carlos - SP - Brazil. ${ }^{5}$ \\ DHB; UFSCar; São Carlos - SP - Brazil. ${ }^{6}$ PPG-SEA; CRHEA; SHS; USP; São Paulo - SP - Brazil
}

\begin{abstract}
The objective of this work was to assess the toxicity of sediment samples from six cascade reservoirs in Tietê river system, in São Paulo State, Brazil, through chronic-partial toxicity bioassays with Danio rerio larvae as testorganisms. Histology of gills and biometric measurements were used to determine the existence of toxicity problems. The alterations on gill morphology here detected were considered of first stage (hyperplasia, lamellar junction and excess of mucous cells) in the first reservoirs and very slight in the last ones. The biometric analysis pointed to inadequate conditions for the growth of the test-organisms when exposed to the sediment of the rivers and upstream reservoirs and also indicated an improvement of environmental conditions along the system.
\end{abstract}

Key words: Gill morphology, sediment toxicity, Danio rerio, Tietê reservoirs, pollution

\section{INTRODUCTION}

Aquatic ecosystems usually reflect all the impacts generated by a variety of activities taking place in the hydrographic basin they are inserted (Tundisi et al., 1999). The sediment compartment is the final receptor of the insoluble (or water weakly soluble) pollutants acting both, as a deposit and also as a source of pollutants to the water column. Pollutants are made available under certain environmental conditions, thus representing a source of diffuse pollution in the water compartment. They affect both nektonic and benthic organisms (Baudo and Muntau, 1990; Plette et al., 1999). The toxicity bioassays together with physical and chemical analyses used to detect and quantify the chemical substances present in water ecosystems - allow the assessment of the effect of toxic agents on the biota (Rand and Petrocelli, 1985). Acute effects, such as mortality and immobility in short exposure time, as well as chronic effects, detected in longer exposures, are important tools for the assessment of pollution effects on the structure of communities. They also contribute to the understanding of the dynamics of aquatic ecosystems as a whole. In this context, biomarkers (biochemical, physiological and histological markers) are important to interpret the toxicity of environmental systems. Among the various biomarkers, the histological analyses of different organs may indicate the biological responses to an unfavorable situation, because often the prolonged exposure of the organisms to toxic agents does not provoke death directly, but it affects the structure and the function of vital organs, jeopardizing the individual, the population

\footnotetext{
* Author for correspondence
} 
and sometimes the species (Poleksic and MitrovicTutundizc, 1994; Au et al., 1999). The gills of aquatic organisms represent primary targets of disturbance by pollutants as they are in direct contact with the external medium to perform gaseous exchanges and ionic regulations. This organ has linking sites to promote its regular functions, and these sites may link to toxic substances with differentiated charges, triggering mechanical responses and toxic effects to the organisms (Hollis and Playle, 1997). According to Ewald (1995), tissue alterations are preceded by biochemical and physiological responses, and once the damage is detected, the adverse effects on the organisms are incontestable. When the alterations occur in organisms exposed to environmental samples, they confirm the degradation of the area. The general objective of this work was to assess the toxicity of samples of sediment collected along six reservoirs built in cascade in Tietê River, Brazil, by means of chronic partial exposure toxicity tests (seven days) with Danio rerio larvae (24 hour old), using the histological analysis of gill tissues and growth alterations of these testorganisms to indicate the possible degradation of this system.

\section{MATERIALS AND METHODS}

\section{Study area and sampling sites}

The study area comprised the rivers Piracicaba and Tietê, as well as six reservoirs (Barra Bonita, Bariri, Ibitinga, Promissão, Nova Avanhandava and Três Irmãos). This area constitutes the Middle and Low Tietê, which flows into Paraná river (Figure 1). This region is characterized by spatial heterogeneity. The Piracicaba river basin consisting of Piracicaba River and the Superior Middle Tietê river basin, including Tietê River and the first reservoir of the system (Barra Bonita) - is characterized by high urban and industrial concentration. Coffee and sugar cane crops predominate in its agriculture area, and its main industries produce paper, cellulose, food, textiles, leather, steel, petrol, sugar and alcohol. There are also some slaughterhouses in its industrial area (CETESB, 1996, 1997). The Bariri, Ibitinga and Promissão reservoirs are in the Inferior Middle Tietê river basin, whose agricultural area comprise coffee, sugar cane, corn and citrus crops and pastures. Industrial activities are related to sugar and alcohol mills, food factories and tanneries (CETESB, 1997). The Low Tietê river basin comprises the last two reservoirs of Tietê river basin ( Nova Avanhandava and Três Irmãos). The surrounding area is predominantly characterized by pastures and sugar cane crops. Its industrial activity is incipient, mostly from sugar mills and food factories. In general, the whole area studied is characterized by the absence of native vegetation and riparian forests. The water resources of the system are destined to public consumption, reception of domestic and industrial effluents, irrigation, navigation and leisure, which make the environmental studies fundamental (CETESB, 1995, 1996, 1997, 1998; CESP, 1998). The sample collection sites were located upstream and downstream the dams of each reservoir besides one site in Piracicaba River and one in Tietê River. Therefore, there were 14 sampling sites (Figure 1). Sampling was carried out in February 2000, corresponding to the dry season.

\section{Sediment sampling}

The sediments were collected by an Eckman-Birge dredge, with three replicates at each site (approximately $1.5 \mathrm{Kg}$ ). The sediments were homogenized and separated in two aliquots. One aliquot was placed in a plastic bag and stored at $4^{\circ} \mathrm{C}$ for 12 days until the moment the toxicity bioassays and the other was dried at room temperature, for subsequent physical and chemical analyses (approximately 20 days).

\section{Physical and chemical analyses of sediment The analysis of the sediment included the determination of the concentrations of bioavailable metals (Rosa and Azcue, 1997), organic matter (Trindade, 1980) and the granulometry (ABNT, 1968).}

\section{Sensibility Tests}

The Danio rerio larvae were utilized 24 hours after hatching, as a maximum age, and submitted to tests of sensibility to potassium dichromate for 24 hours, at ten different concentrations, to determine the LC50, according to ABNT (1993) to assess the health of the test-organisms. After that these organisms were then used in the toxicity bioassays with sediments. 


\section{Toxicity bioassays of sediment}

The bioassays were performed according to the methodology described by Burton and MacPherson (1995) for fish larvae, keeping the sediment and reconstituted water at the ratio 1:4 (200g of sediment and $800 \mathrm{ml}$ of reconstituted water), three replicates and 10 organisms in each experimental flask $(1.200 \mathrm{ml})$. The aeration was constant, the temperature was controled $26 \pm 2{ }^{\circ} \mathrm{C}$ and photoperiod of 12:12 dark:light. The $\mathrm{pH}$, conductivity and hardness were monitored every 48 hours to better understand the dynamics of the sediment during the bioassays (ABNT, 1993). The organism used was Danio rerio larvae (24 hours after eclosion). It was acquired as eggs (eclosion at the laboratory). The control tests were done with reconstituted water (ABNT, 1993) and sediments of the area not polluted (Broa Reservoir, an oligotrophic artificial lake in São Paulo state). The bioassays lasted seven days, which allowed the organisms not to be fed, since they fed on their own vitellus during this period.

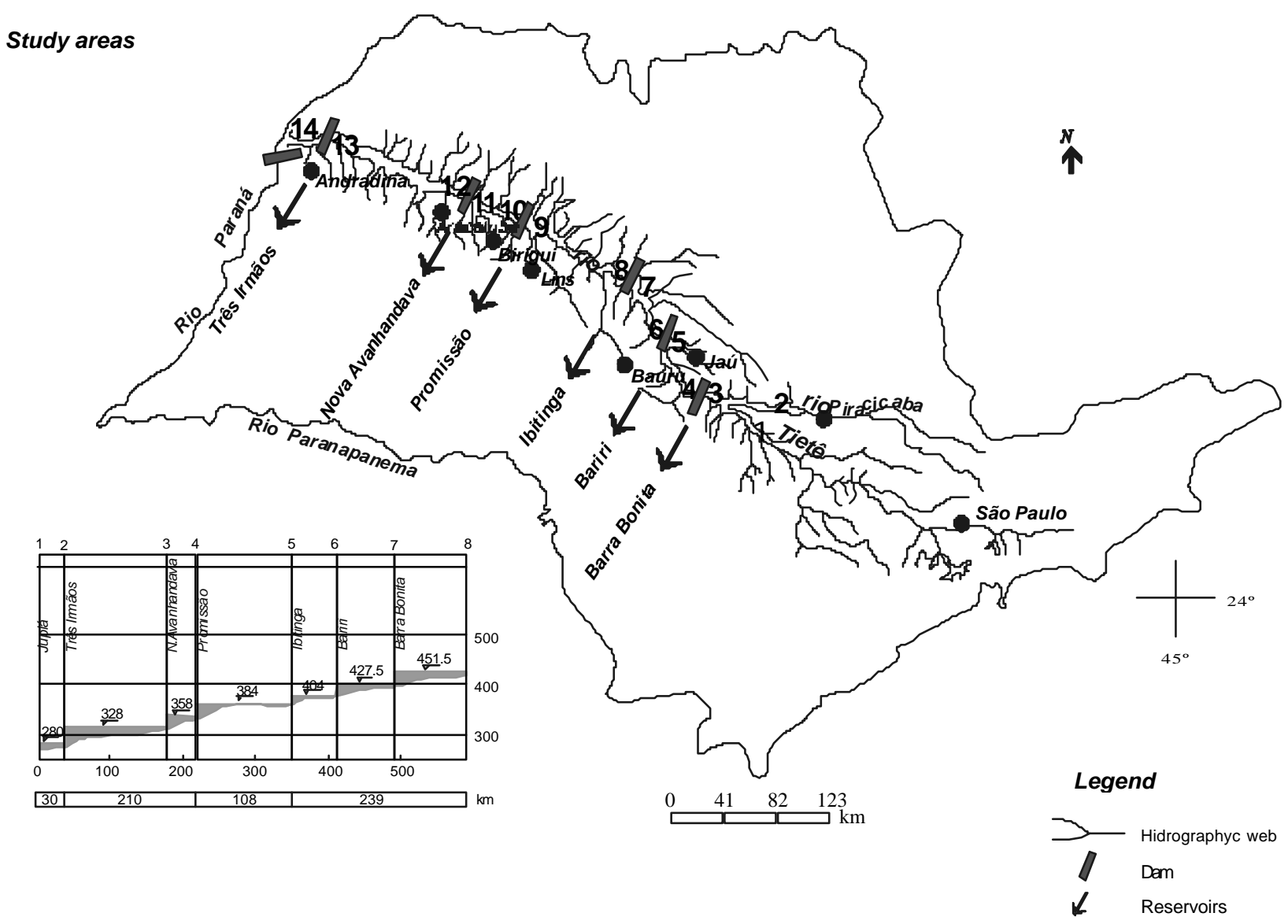

Figure 1 - Map of studied area showing sampling sites and distance between dams in Km (picture down map). Source: PPDI (1982), Drawing: Cristina Criscuolo

\section{Environmental toxicity}

The toxicity evaluation of the environmental samples was based on the mortality percentage proposed by Prater and Anderson (1977) which considered mortality percentages from 1 to $25 \%$ as low environmental toxicity, from 26 to $50 \%$ as medium toxicity and from 51 to $100 \%$ as high toxicity.

\section{Weight and total length measurements}

The weight and total length of the surviving organisms in the bioassays were evaluated with a high precision scale and gage, respectively. The data were compared statistically to the measures obtained with the control organisms through ManWhitney non-parametric test (ZAR, 1999), allowing the detection of chronic effects on the 
growth and development of test organisms. This assessment was not done with the bioassays that produced mortality above $90 \%$, due to deficient data.

\section{Histological assessment of the gills}

After the end of the bioassays, the surviving organisms were counted and fixed in GTA $2.5 \%$, included as whole in historesin LKB and later cut serially with a $2.0 \mu \mathrm{m}$-thick steel razor microtom (Micron HM 340E).

Table 1 - Granulometric composition of sediments at the sampling sites

\begin{tabular}{cccccc}
\hline \multirow{2}{*}{ Sampling sites } & \multicolumn{5}{c}{ Granulometry (\%) } \\
\cline { 2 - 6 } & GS & MS & FS & S & CL \\
\hline P & 3 & 3 & 13 & 16 & 65 \\
T & 5 & 2 & 11 & 12 & 70 \\
BBM & 1 & 2 & 12 & 85 & 0 \\
BBJ & $*$ & $*$ & $*$ & $*$ & 0 \\
BM & 3 & 14 & 32 & 51 & 0 \\
BJ & 2 & 3 & 24 & 70 & 0 \\
IM & 2 & 2 & 8 & 88 & 0 \\
IJ & 0 & 2 & 26 & 72 & 0 \\
PM & 0,5 & 2,5 & 16 & 23 & 0 \\
PJ & 1 & 3 & 73 & 84 & $*$ \\
NAM & 4 & 2 & 10 & 5 & 0 \\
NAJ & $*$ & $*$ & 9 & 0 & 0 \\
TIM & 0 & 0 & 95 & & 0 \\
TIJ & 0 & 2 & & & 0 \\
\hline
\end{tabular}

GS -Gross sand; MS - Midlle sand; FS-Fine sand; S-Silty; CL-clay.

P-Piracicaba; T-Tietê; BBM-Barra Bonita upstream; BBJ-Barra Bonita downstream ; BM-Bariri upstream; BJ-Bariri downstream; IM-Ibitinga upstream; IJ-Ibitinga downstream; PM-Promissão upstream; PJ-Promissão downstream; NAM -Nova Avanhandava upstream; NAJ-Nova Avanhandava downstream, TIM-Três Irmãos upstream ; TIJ-Três Irmãos downstream .

*Insufficient samples to perform granulometric analysis

Table 2 - Percentage of organic and inorganic matter obtained in sediments of different sampling sites in Tietê system, Brazil.

\begin{tabular}{ccc}
\hline & \multicolumn{2}{c}{ \% organic and inorganic matter } \\
\cline { 2 - 3 } Sampling sites & OM & IM \\
\hline P & 10.92 & 89.07 \\
T & 13.92 & 86.07 \\
BBM & 12.70 & 87.30 \\
BBJ & 7.90 & 92.10 \\
BM & 14,34 & 85.50 \\
BJ & 11.54 & 88.45 \\
IM & 9.98 & 90.01 \\
IJ & 11.13 & 88.86 \\
PM & 12.05 & 87.94 \\
PJ & 0.70 & 99.30 \\
NAM & 12.80 & 87.20 \\
NAJ & 0.10 & 99.90 \\
TIM & 0.30 & 99.30 \\
TIJ & 0.50 & 99.50 \\
\hline
\end{tabular}

P-Piracicaba; T-Tietê; BBM-Barra Bonita upstream; BBJ-Barra Bonita downstream ; BM-Bariri upstream; BJ-Bariri downstream; IM-Ibitinga upstream; IJ-Ibitinga downstream; PM-Promissão upstream; PJ-Promissão downstream; NAM -Nova Avanhandava, NAJ-Nova Avanhandava downstream, TIM-Três Irmãos upstream; TIJ-Três Irmãos downstream .OM-organic matter; IM-inorganic matter 
The stain used was the toluidine blue and the tissues were observed under a light microscope. The lesions found in the test-organisms were described according to the categories proposed by Poleksic and Mitrovic-Tutundizc (1994).

\section{RESULTS AND DISCUSSION}

The granulometric analysis showed a spatial heterogeneity of the sediment, with predominance of clay in rivers Piracicaba and Tietê, silt in some sites upstream Barra Bonita and Nova Avanhandava dams - except for downstream Promissão dam, where the predominant fraction was fine sand, matching the composition of the sediments from downstream Nova Avanhandava to downstream Três Irmãos dams (Table 1).

With respect to the percentage of organic matter, the sediments of the rivers - up to the site corresponding to upstream Nova Avanhandava dam - displayed similar concentrations, ranging from $14.34 \%$ (upstream Bariri dam) to $7.90 \%$ (downstream Barra Bonita dam), except for downstream Promissão dam $(0.70 \%)$ and from downstream Nova Avanhandava dam to downstream Três Irmãos dam, whose percentages were low: $0.1,0.3 \%$ and $0.5 \%$, respectively (Table 2).

However, inorganic matter predominated in all sampling sites. These conditions indicated at that the rivers and the first sampling sites were more likely to retain pollutants with particle electrical charges, probably due to the adsorption of the small sediment particles to the high quantity of organic matter which contributed to the higher toxicity rate of the compartment (Esteves, 1982). This factor and the fact that the rivers and the beginning of the reservoir cascade were located near urban and industrial centers - thus suffering more intense anthropogenic impacts, besides the absence of native vegetation - caused more severe diffuse pollution. This situation allowed higher bioavailability of toxic substances for the water column under certain environmental conditions (low $\mathrm{pH}$, low hardness, oxygen depletion and the type of pollutant, as heavy metals for example).

Table 3 - Concentration of bioavailable metals in sediments of rivers and reservoirs of the Tietê system, Brazil.

\begin{tabular}{|c|c|c|c|c|c|c|c|c|c|}
\hline $\begin{array}{c}\text { Metals } \\
(\mathrm{mg} / \mathrm{Kg}) \\
\Rightarrow \\
\text { Sites } \Downarrow\end{array}$ & $\begin{array}{l}\text { Cadmium } \\
\quad(\text { Cd })\end{array}$ & $\begin{array}{r}\text { Lead } \\
(\mathbf{P b})\end{array}$ & $\begin{array}{c}\text { Cobalt } \\
(\text { Co })\end{array}$ & $\begin{array}{l}\text { Copper } \\
\text { (Cu) }\end{array}$ & $\begin{array}{l}\text { Cromium } \\
\quad(\mathrm{Cr})\end{array}$ & $\begin{array}{l}\text { Iron } \\
(\mathrm{Fe})\end{array}$ & $\begin{array}{l}\text { Magnesium } \\
\text { (Mg) }\end{array}$ & $\begin{array}{l}\text { Mangan } \\
\text { ese (Mn) }\end{array}$ & $\begin{array}{l}\text { Zinc } \\
(\mathrm{Zn})\end{array}$ \\
\hline $\mathrm{P}$ & 0.80 & 10.00 & 23.00 & 22.80 & 11.40 & 4698.40 & 592.40 & 1106.60 & 62.94 \\
\hline $\mathrm{T}$ & 0.80 & 20.00 & 18.00 & 16.00 & 6.20 & 4042.40 & 282.82 & 1426.40 & 68.14 \\
\hline BBM & 0.80 & 14.00 & 7.40 & 18.80 & 3.60 & 4226.00 & 291.60 & 1780.00 & 38.46 \\
\hline BBJ & 1.00 & 14.00 & 21.20 & 37.20 & 10.40 & 9322.80 & 451.20 & 1585.00 & 41.42 \\
\hline $\mathrm{BM}$ & 1.00 & 14.00 & 11.80 & 29.00 & 6.40 & 6090.00 & 422.00 & 1544.40 & 31.54 \\
\hline BJ & 1.00 & 12.00 & 13.40 & 32.00 & 6.80 & 4530.80 & 343.60 & 1474.00 & 26.60 \\
\hline IM & 0.60 & 4.00 & 13.80 & 20.40 & 9.00 & 3045.00 & 345.60 & 180.40 & 16.60 \\
\hline IJ & 0.80 & 8.00 & 23.40 & 21.00 & 10.80 & 4405.00 & 253.40 & 283.40 & 3.44 \\
\hline PM & 0.60 & 2.00 & 66.00 & 15.80 & 6.60 & 4146.00 & 253.40 & 238.20 & 3.26 \\
\hline PJ & 0.60 & 6.00 & 24.00 & 1.80 & 4.40 & 582.20 & 136.76 & 172.20 & 2.04 \\
\hline NAM & 1.60 & 16.00 & 26.60 & 35.60 & 7.80 & 3216.00 & 271.40 & 41.00 & 6.56 \\
\hline NAJ & 0.40 & 4.00 & 0.00 & 0.80 & 5.60 & 224.00 & 54.64 & 106.80 & 1.20 \\
\hline TIM & 1.80 & 6.00 & 0.00 & 0.80 & 0.00 & 137.20 & 75.60 & 12.50 & 1.34 \\
\hline TIJ & 0.60 & 6.00 & 0.00 & 1.20 & 0.00 & 5.64 & 58.80 & 8.20 & 0.00 \\
\hline
\end{tabular}

P-Piracicaba; T-Tietê; BBM-Barra Bonita upstream; BBJ-Barra Bonita downstream ; BM-Bariri upstream; BJ-Bariri downstream; IM-Ibitinga upstream; IJ-Ibitinga downstream; PM-Promissão upstream; PJ-Promissão downstream; NAM -Nova Avanhandava upstream; NAJ-Nova Avanhandava downstream, TIM-Três Irmãos upstream ; TIJ-Três Irmãos downstream.

Bioavailable metals were present along the cascade, but their concentrations decreased towards the last reservoir - except for cadmium, whose concentration was relatively high at the last sites of the system (Table 3). These results confirmed that althought most of the parameters evaluated in the sediments showed an improvement of the environmental quality towards the last reservoirs, punctual and diffuse pollution also occured around each water body separately, contributing to the degradation of these environments. Therefore, these analyses indicated the toxic potential of the sediment in all reservoirs, related to the conditions of mortality and chronic 
effects assessed in this study. The toxicity bioassays revealed that the sediments from rivers Piracicaba and Tietê, and those from the first reservoirs caused high mortality percentages, probably due to high toxic load from large urban and industrial centers such as the São Paulo city and Americana regions (Tabela 4). Theorically, in reservoirs built in cascade, the environmental quality of the last reservoirs tends to improve, as the water bodies upstream tend to retain part of the pollutants, preventing damage to subsequent reservoirs (Straskraba, 1996). However, although in the last reservoir (Três Irmãos) the lowest mortality percentages were found, it was possible to observe variations in the response of larvae along the system, indicating once more the existence of localized impacts from the surrounding activities on the water bodies. The fact that the last reservoirs are the most recent (as regards construction) may imply less bioavailability of pollutants for the water column. Nevertheless, it was possible to observe a relatively high mortality percentage in the bioassays with sediment samples from upstream and downstream Nova Avanhandava dam, corresponding to $43.33 \%$. This result was in accordance with the analysis of bioavailable metals that might have been released during the period of the bioassays, causing the death of part of the test-organisms. Fracácio (2000), studying the Tietê system, detected through toxicity bioassays with sediments the release of metals and nutrients to the water. This confirmed the toxic potential of the sediments to the water column organisms with respect to the bioavailability of toxic pollutants. Chronic alterations regarding the development of the surviving organisms could be observed since significant differences for their weight and length were found, when compared to the same parameters assessed for the control individuals, in some of the sediments tested (Table 5).

Table 4 - Mortality percentage and environmental toxicity rate for sample collection sites in Tietê system, Brazil.

\begin{tabular}{|c|c|c|c|c|c|c|c|c|}
\hline \multirow[t]{2}{*}{ Sampling sites } & \multicolumn{2}{|c|}{ pH } & \multicolumn{2}{|c|}{$\begin{array}{c}\text { Conductivity } \\
(\mu \mathrm{S} / \mathrm{cm})\end{array}$} & \multicolumn{2}{|c|}{$\begin{array}{c}\text { Hardness } \\
\left(\mathrm{mg} \mathrm{CaCO}_{3} / \mathrm{L}\right)\end{array}$} & \multirow[t]{2}{*}{ Mortality (\%) } & \multirow[t]{2}{*}{ Toxicity } \\
\hline & $\mathbf{B}$ & $\mathbf{E}$ & B & $\mathbf{E}$ & B & $\mathbf{E}$ & & \\
\hline $\mathrm{C}$ & 7.52 & 7.14 & 164 & 126.9 & 40 & 26 & 6.66 & acceptance \\
\hline $\mathrm{P}$ & 7.52 & 5.76 & 136 & 166.9 & 40 & 40 & 60.00 & HT \\
\hline $\mathrm{T}$ & 7.52 & 5.78 & 136 & 198.0 & 40 & 38 & 66.66 & HT \\
\hline $\mathrm{BBM}$ & 7.52 & 5.65 & 136 & 223.0 & 40 & 24 & 93.33 & HT \\
\hline $\mathrm{BBJ}$ & 7.52 & 6.33 & 136 & 142.3 & 40 & 38 & 60.0 & HT \\
\hline $\mathrm{BM}$ & 7.52 & 6.09 & 136 & 133.7 & 40 & 30 & 33.33 & MT \\
\hline BJ & 7.52 & 7.14 & 136 & 126.9 & 40 & 26 & 26.66 & $\mathrm{LT}$ \\
\hline IM & 7.52 & 6.77 & 136 & 131.5 & 40 & 32 & 33.33 & MT \\
\hline $\mathrm{IJ}$ & 7.52 & 6.88 & 136 & 128.3 & 40 & 26 & 33.33 & MT \\
\hline PM & 7.52 & 6.38 & 136 & 93.7 & 40 & 20 & 43.33 & MT \\
\hline PJ & 7.52 & 7.06 & 136 & 214 & 40 & 68 & 30.00 & LT \\
\hline NAM & 7.52 & 6.83 & 136 & 125.2 & 40 & 36 & 43.33 & MT \\
\hline NAJ & 7.52 & 7.09 & 136 & 143.8 & 40 & 36 & 43.33 & MT \\
\hline TIM & 7.52 & 7.22 & 136 & 195.3 & 40 & 56 & 10.00 & LT \\
\hline TIJ & 7.52 & 7.13 & 136 & 130.7 & 40 & 34 & 6.66 & LT \\
\hline
\end{tabular}

HT-Hight toxicity; MT-midlle toxicity; LT - Less toxicidade.B -beginning; E - end.

C-Control; P-Piracicaba; T-Tietê; BBM-Barra Bonita upstream; BBJ-Barra Bonita downstream ; BM-Bariri upstream; BJ-Bariri downstream; IM-Ibitinga upstream; IJ-Ibitinga downstream; PM-Promissão upstream; PJ-Promissão downstream; NAM -Nova Avanhandava upstream ; NAJ-Nova Avanhandava downstream, TIM-Três Irmãos upstream and TIJ-Três Irmãos downstream. 
Table 5 - Alterations of weight and length as compared to measures obtained from control organisms by means of Mann-Whitney test.

\begin{tabular}{ccc}
\hline Sampling sites & $\begin{array}{c}\text { Lengt Total } \\
(\mathbf{m m})\end{array}$ & $\begin{array}{c}\text { weight total } \\
(\mathbf{g})\end{array}$ \\
\cline { 2 - 3 } & $\mathbf{p}$ & $\mathbf{p}$ \\
\hline P & $<0.001$ & $<0.01$ \\
T & $<0.001$ & $<0.01$ \\
BBM & $*$ & $*$ \\
BBJ & $<0.001$ & $>0.05$ \\
BM & $<0.001$ & $>0.05$ \\
BJ & $>0.05$ & $>0.05$ \\
IM & $<0.001$ & $>0.05$ \\
IJ & $<0.05$ & $>0.05$ \\
PM & $>0.05$ & $>0.05$ \\
PJ & $>0.05$ & $>0.05$ \\
NAM & $>0.05$ & $>0.05$ \\
NAJ & $>0.05$ & $>0.05$ \\
TIM & $>0.05$ & $>0.05$ \\
TIJ & $>0.05$ & $>0.05$ \\
\hline
\end{tabular}

P-Piracicaba; T-Tietê; BBM-Barra Bonita upstream; BBJ-Barra Bonita downstream ; BM-Bariri upstream; BJ-Bariri downstream; IM-Ibitinga upstream; IJ-Ibitinga downstream; PM-Promissão upstream; PJ-Promissão downstream; NAM -Nova Avanhandava upstream; NAJ-Nova Avanhandava downstream, TIM-Três Irmãos upstream ; TIJ-Três Irmãos downstream .

* mortality above $90 \%$.

The objective of the histological assessment of the gill was to verify the possible damage caused by the exposure of the organisms to environmental samples, evidencing alterations resulting from the chronic-partial bioassays. The gills have a large superficial area through which gaseous exchanges between the blood and the external medium take place (Newstead, 1987). Besides the respiratory function, this organ performs other vital functions as osmoregulation and excretion (Mallat, 1985). The direct contact between this organ and water promotes the interaction with toxic substances present in the water as they have sites of ionic links to perform normal functions. Adsorption of metals and other pollutants with charges may eventually occur, bringing about toxic effects on the organisms (Hollis and Playle, 1997). The thin epithelial layer that covers the secondary lamellae represents the largest site for gaseous exchanges. The chloride cells, responsible for ionic exchanges, are usually concentrated in the primary lamella, but also distributed among the secondary lamellae under conditions of low ionic concentrations. Besides transporting $\mathrm{Na}^{+}, \mathrm{Cl}^{-}$e $\mathrm{Ca}^{+}$, these cells may eventually accumulate toxic metals and other substances. Although the evaluation of the gill morphology of larvae exposed to the sediment of most of the sites of the Tietê system for a chronic period revealed minor alterations, it shows signs of potential toxicity in these environments. Excessive cell proliferation was observed at all sites, less intensely in organisms exposed to sediments from Nova Avanhandava and Três Irmãos dams (upstream and downstream) (Figures 2G and $2 \mathrm{H}$ ). This alteration indicates a morphological response as an attempt to protect the organism by increasing the water-blood barrier to bio-available toxic pollutants. When the space between the secondary lamellae, through which gaseous exchanges occur, becomes very small, it may cause the fish to asphyxiate. As compared to the gill morphology of the control organisms (Figure 2A), cell proliferation was observed, culminating at the junction of two secondary lamellae in the fishes exposed to the sediments from the sites corresponding to rivers Piracicaba and Tietê, Barra Bonita dam (upstream and downstream) and Promissão dam (downstream) (Figures $1 \mathrm{~B}$ and 1D). According to Sorensen (1991), the exposure of Fundulus heteroclitus to 50ppm of cadmium during 48 hours caused some alterations in the gill epithelia, such as hyperplasia, increase in the activity of mucous cells and hypertrophy. With respect to copper, a $64 \mathrm{ppb}$ concentration during 48 hours caused the junction of gill lamellae in Salmo gairdneri (Bilinsk and Jonas, 1973). 

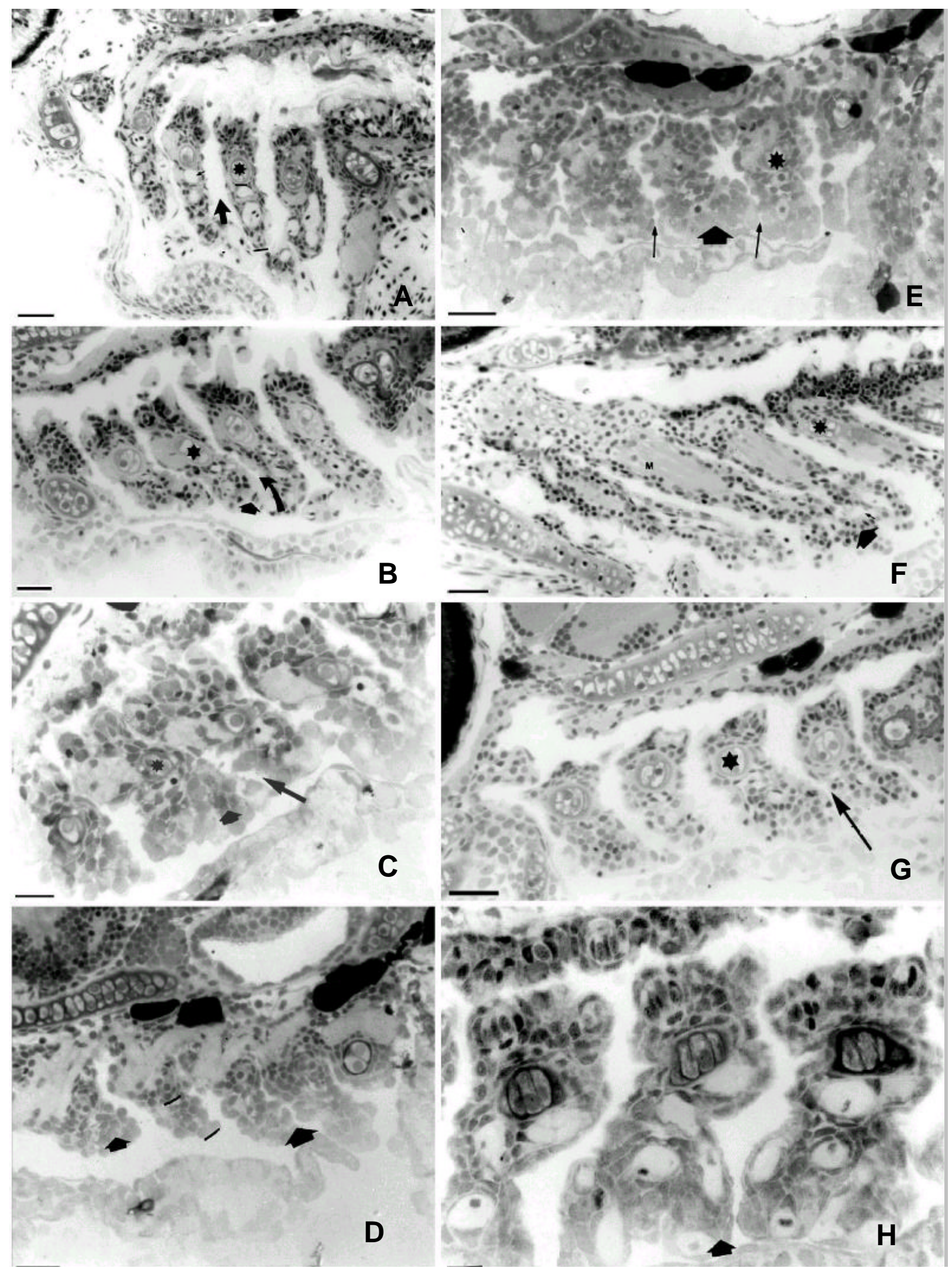

Figure 2 - Mean histological alterations of gill structure of organisms exposed to sediments of the Tietê river reservoirs (Brazil) (sagital sections, toluidine blue). A. Control organism, showing cartilage (*), normal development in the respiratory area ( ||); interllamellar space $(\rightarrow)$. Bar: $34 \mu \mathrm{m}$; B. Organism-Ibitinga 


\begin{abstract}
upstream; note the cartillage (*), the cell proliferation in the respiratory area (\$), and the reduced interlamellar space ( $)$. Bar: $34 \mu \mathrm{m}$. C. Organism-Tietê river, showing the cartilage (*), lamellar cell hiperplasia $(\$)$ and fusion of the secondary lamelae $(\rightarrow)$. Bar:34 $\mu \mathrm{m}$. D. Organism-Barra Bonita upstream, note the cell proliferation (\$), reduced: interlamellar spaces (\$) and respiratory area (| |). Bar: $34 \mu \mathrm{m}$. E. Organism-Barra Bonita dowstream, showing cell proliferation (\$), cartilage (*) and reduced interlamellar epace $(\rightarrow)$. Bar: $34 \mu \mathrm{m}$. F. Organism-Bariri upstream, note note the cell proliferation at the lamellae tips ( ) , predominance of muscular tissue $(M)$ and hiperplasia of mucous cells $(p)$ in the filament. Bar: $34 \mu \mathrm{m}$. G. Organism-Nova Avanhandava upstrean, showing cell lamellar proliferation $(\rightarrow)$ and cartilage (*). Bar: $34 \mu \mathrm{m}$. H. Organism-Três Irmãos dowstream, note the lamelar cell proliferation. Bar: $17 \mu \mathrm{m}$.
\end{abstract}

Rigolin-Sá (1998), assessing the toxicity of Roundup ${ }^{\circledR}$ herbicide and Omite ${ }^{\circledR}$ acaricide on initial ontogenetic phases of Rhamdia hilarii, observed cell proliferation in the gills of the animals exposed to all different concentrations tested. In the highest Roundup concentrations, the author verified the total alteration of interlamellar tissues, with their complete junction. Other alterations such as enlargement of blood vessels, aneurysm and cellular necrosis were observed. According to Karlsson-Norrgren et al. (1985), the concentration of heavy metals has increased considerably in water bodies in several countries due to anthropogenic activities. These authors, evaluating the exposure of Danio rerio and Salmo gairdnei to different concentrations of cadmium for six and four weeks, respectively, verified an increase in the volume of the secondary lamellae in Danio rerio, filling in the interlamellar space, starting from the concentration $10 \mu \mathrm{g} / \mathrm{L}$, resulting in the decrease of the diffusion capacity. The same alterations were observed in Rainbow trout in just 4 weeks of assay. Karlsson-Norrgren and Runn (1985), assessing the cadmium dynamics in adult Danio rerio females, verified that within 24 hours this element had already been incorporated by the gills, skin and part of the digestive tract at $10 \mu \mathrm{g}$ $\mathrm{Cd} / \mathrm{L}$. Within 7 days, the gills had incorporated $65 \%$ of the cadmium. Therefore, for fishes inhabiting Tietê reservoirs, their gills are subject to toxicity by metals, detected in the sediments of this study. In the samples from Bariri reservoir (upstream), besides gill disorganization, there was excessive proliferation of mucous cells, a probable morphological response to the high quantity of ions present in the water of the bioassays. Mucous cells are characterized by the presence of large secretion granules, which occupy most of the cytoplasm. When these grains are secreted, they originate a layer of mucus that assist in the defense processes against pathogenic agents and in the osmotic and ionic regulation (Andrade, 1999). It is known that metals causes damage to gill tissues and can induce fish mortality by the excessive cell proliferation and mucous production (Sorensen, 1991). Fish may asphyxiate due to excessive mucus, also produced in the presence of several metals. According to Perry (1997), the adaptive responses to variations in ionic concentrations of the water medium involve a morphologic component related to the chloride cells of the gills responsible for ionic regulation. Water poor in ions causes the proliferation of these cells, which increase the water-blood barrier and may provoke a respiratory malfunction. The gills of the test-organisms evaluated in this study did not show alterations in relation to chloride cells, which were seldom detected. Mallatt (1985) studied the main structural changes induced by toxic substances and other chemicals in the gill structure of fish and verified that the most common lesions were necrosis, hyperplasia, hypertrophy and rupture of gill tissues, lamellar fusion, hypersecretion and proliferation of mucous cells, alterations in chloride cells and vascularization. According to the typology proposed by Polëksic and Mitrovic-Tutundzic (1994), there are three phases of gill alterations where there is progressive worsening of the lesions. The first phase is when the damage may be reversed under satisfactory conditions for the organisms. In case the conditions remain unfavorable, the lesions reach the second phase. In this phase the lesions are more severe and difficult to reverse. In case of chronic exposure the lesions reach a third phase, in which the reparation of the gill structure is irreversible, jeopardizing its vital functions and eventually causing the organisms to die. The fact that the organisms showed some tissue disorganization, even relative to the first stage, indicated that the conditions of the medium were not favorable to the development and 
survival of water organisms. Although the chronic morpho-functional alterations verified in the test organisms might have been caused by other pollutants not assessed in this work, which could have been present in the sediments and become bio-available, the mortality results, histological conditions (Figures 2B, 2C, 2D 2E 2F, 2G and 2H) and growth alterations of the test organisms associated with the chemical conditions of the sediments detected in this work confirmed the environmental degradation. This degradation was probably related to agriculture, industrial and domestic sewage from urban centers around the beginning of this system. The quality improvement of the sediments towards the last reservoirs could also be observed from the data showing less severe morphological lesions and absence of weight and length alterations of the test-organisms.

\section{ACKNOWLEDGEMENTS}

The authors wish to express their appreciation for the financial support of the Brazilian research institutions (CAPES and MMA-PROBIO), as well as the PPG-SEA/SHS/EES/USP and Laboratory of Dynamics of Fishers Populations (DHB/UFSCAR).

\section{RESUMO}

Os bioensaios de toxicidade com amostras ambientais avaliam as respostas dos organismos teste frente a possíveis poluentes. Ocorrem em complementação às análises limnológicas da água e sedimento, uma vez que estas apenas identificam e quantificam as diferentes substâncias nestes compartimentos aquáticos. $\mathrm{O}$ objetivo deste trabalho foi avaliar a toxicidade das amostras de sedimentos dos seis reservatórios em cascata do sistema Tietê (SP) - Brasil, através de bioensaios de toxicidade crônico-parciais utilizando como organismos-teste larvas de Danio rerio. A histologia das brânquias e as medidas biométricas foram as ferramentas utilizadas para averiguar o problema ambiental. As alterações branquiais detectadas foram de primeiro grau (hiperplasia, junção lamelar e excesso de células mucosas) e pouco acentuadas nos últimos reservatórios. As análises biométricas demonstraram condições inadequadas ao desenvolvimento dos organismos testes frente a possíveis poluentes biodisponíveis nos sedimentos dos rios e primeiros reservatórios, confirmando a melhoria das condições ambientais ao longo da cascata. Isto também pode ser confirmado através das análises químicas dos sedimentos deste sistema.

\section{REFERENCES}

Associação Brasileira de Normas Técnicas - ABNT (1968), Análise granulométrica de solos. 32p.

Associação Brasileira de Normas Técnicas - ABNT (1993), NRB 12714. Água - Ensaio de toxicidade aguda com peixes. Parte I - Sistema Estático. Rio de Janeiro, 15p.

Andrade, C. A. (1999), Efeito da concentração iônica do meio aquático nas células mucosas de Traíra, Hoplias malabaricus e Jeju, Hoplerythrinus unitaeniatus (Teleostei, Erythrinidae). Monografia. Universidade Federal de São Carlos, São Carlos, Brasil.

Au, D. W. T; Wu, R. S. S.; Zhou, B. S. and Lam, P. K. S. (1999), Relationship btween ultrastructural changes and EROD activities in liver of fish exposed to benzo [a] pyrene. Environmental Pollution, (104), 235-247.

Baudo, R. and Muntau, H. (1990), Lesser Known inplace pollutants and diffuse source problems. In: Baudo, R.; Giesy, J. P. and Muntau, H. Sediments: chemistry and toxicity of in-place pollutants. Boca Raton, Lewis Publishers, Inc. 1, 1-14.

Bilinsk, E. and Jonas, R. E. E. (1973), Effects of cadmium and copper on the oxidation of lactate by rainbow trout (Salmo gairdineri) gills. J. Fish. Res. Bd. Can., 30, 1553.

Burton, G. L. and Macperson, C. (1995), Sediment toxicity testing issue and methods. In: Hoffman, D. J., et. al. Handbook of ecotoxicology. Boca Raton, Lewis Publishers. pp. 70-103.

Companhia Energética de São Paulo - CESP (1998), Conservação e manejo nos reservatórios: limnologia, ictiologia e pesca. $163 \mathrm{pp}$.

Companhia de Tecnologia e Saneamento Ambiental CETESB - (1995), Relatório da Qualidade das Águas Interiores do Estado de São Paulo - 1994. 269 pp.

Companhia de Tecnologia e Saneamento Ambiental CETESB - (1996), Relatório da Qualidade das Águas Interiores do Estado de São Paulo - 1995. 288 pp.

Companhia de Tecnologia e Saneamento Ambiental CETESB - (1997), Relatório da Qualidade das Águas Interiores do Estado de São Paulo - 1996. 285 pp.

Companhia de Tecnologia e Saneamento Ambiental CETESB - (1998), Relatório da Qualidade das Águas Interiores do Estado de São Paulo - 1997. 267 pp. 
Esteves, F. A. and Camargo, A. F. M. (1982), Caracterização do sedimento de 17 represas do Estado de São Paulo, com base no teor de feopigmentos, carbono e nitrogênio orgânico. $\mathrm{Ci} e$ Cult., 5, 669-674.

Ewald, G. (1995), Crhronic measures of toxicant induced effects on fish. Ann Zool. Fenici, 32, 311-316.

Fracácio, R. (2000), Utilização de bioensaios ecotoxicológicos com Danio rerio (Cypriniformes, Cyprinidae) e análises limnológicas para a avaliação ambiental dos reservatórios do Médio e Baixo rio Tietê (SP). Dissertação de mestrado, Universidade de São Paulo, São Carlos, Brasil.

Hollis, L. and Playle, R. C. (1997), Influence of dissolved organic matter on copper binding, and calcium on cadmium binding, by gills of raiwbow trout. Journal of Fish Biology, 50, 703-720.

Karlsson-Norrgren, L. and Runn, P. (1985), Cadmium dynamics in fish: pulse studies with ${ }^{109} \mathrm{Cd}$ in female zebrafish, Brachydanio rerio. J. Fish. Biol., 27, 571-581.

Karlsson-Norrgren, L.; Runn, P.; Haux, C. and Forlin, L. (1985), Cadmiun - induced changes in gill morphology of zebrafish, Brachydanio rerio (Hamilton-Buchanan), and rainbow trout, Salmo gairdneri Richardison. J. Fish. Biol., 27, 81-95.

Mallat, J. (1985), Fish gill structural changes induced by toxicants and other irritants: a statistical review. Can. J. Aquatic. Sci., 42, 189-206.

Newstead, J. D. (1987), Fine struture the respiratory lamellae of Teleostean gills. Zeitsehrif fur Zelfforschung, 70, 420-445.

Perry, S. (1997), The cloride cell: structure and function in the gill of freshwater fishes. Annu. Ver. Physiol., 59, 325-347.

Poleksic. V. and Mitrovic-Tutundizic, V. (1994), Fish gillsmonitor of sublethal and chronic effects of pollution. In: Muller,R. and Lloyd, R. Sublethal and Chronic effects of Pollutants on freshwater fish. United Nation, Fishing News Books. pp. 339-352.

Política de Desenvolvimento e Desconcentração Industrial - PPDI (1982), Diretrizes Para a Política de Desenvolvimento e Desconcentração Industrial. Governo do Estado de São Paulo. 133 pp.

Prater, B. L. and Anderson, M. A. (1977), A 96 hour bioassay of Duluth and Superior harbor basins (Minnesota) using Hexagenia limbata, Aselus communis, Daphinia magna, and Pimephales promelas as test organisms. Bull. Environm. Contam. Toxicol, 18, 159-169.
Rand, G. M. and Petrocelli, S. R. (1985), Introduction. IN: Rand, G.M., Petrocelli, S.R. Fundamentals of aquatic toxicology: methods and application. London, Hemisphere Publishing Corporation. Cap.1. pp. 1-28.

Rigolin-Sá, O. (1998), Toxicidade do herbicida Roundap ${ }^{\circledR}$ (glifosfato) e do acaricida Omite $\mathbb{B}$ (propargito) nas fases iniciais da ontogenia do bagre, Rhandia hilari (VALENCIENNES, 1840) (Pimelodidade, Siluriforme). São Carlos. Tese (Doutorado) - Universidade Federal de São Carlos.

Rosa, F. and Azcue, J. M. (1997), Peeper Methodology. A detailed procedure from field experience. NWRI, Burligton, Canada.

Sorensen, E. M. B. (1991), Metal poisoning in fish. Boca Raton, Press. 322 pp.

Straskraba, M. (1996), Lake and Reservoir Management. Verh. Internat. Limnol., (26), 193-209.

Trindade, M. (1980), Nutrientes em sedimentos da represa do Lobo (Brotas - Itirapina). São Carlos. Dissertação (Mestrado). Universidade Federal de São Carlos. 219 pp.

Tundisi, J. G.; Matsumura-Tundisi, T. and Rocha, O (1999), Theorical Basis for Reservoir Management. In: Tundisi, J. G. and Straskraba, M. Theorical Reservoir Ecology and Its Application. São Carlos, SP. 52 ap.: il. pp. 505-528.

Zar, J. H. (1999), Biostatistical Analysis. Prentice Hall, New Jersey, 4. ed. 663 pp.

Received: November 09, 2001; Revised: July 23, 2002; Accepted: May 08, 2003. 